\title{
An investigation into the different styles of the lawyer and construction specialist when mediating construction disputes
}

\section{Introduction}

The inspiration for this research was the findings of the empirical analysis undertaken by Agapiou and Clark (2012; 2013) regarding Scottish construction mediation. Their study highlighted that Scottish contractors and sub-contractors held a strong preference for mediators with specialist construction industry experience. This view is supported by Brooker (2011) who states that knowledge and awareness of construction industry practice is critically important for resolving disputes in mediation.

The legal profession dominates construction mediation in both England and Wales with lawyers either as mediators or as advisors representing their clients (Gould, 2009; Brooker, 2007; 2011). The review undertaken by the Technology and Construction Court showed that, $41 \%$ of mediations were undertaken by solicitors, $34 \%$ by Barristers, $7 \%$ by judges and only $7 \%$ by other construction professionals (Gould et al., 2010). The Centre for Effective Dispute Resolution in their audit undertaken in 2010 also highlighted that over $80 \%$ of practising mediators in England and Wales come from a legal background (Gould et al., 2010).

Burns (2013) argues that the construction specialist will be quick to appreciate what the parties really want and will not focus wholly on entitlement in moving matters towards a settlement whereas lawyers are experienced in focusing on parties' entitlement which in mediation potentially creates a situation of polarisation

There is growing concern regarding the dominant use of the evaluative style in the mediation of construction disputes in preference to the facilitative style specifically in the USA (Alexander, 2006). Gould (2009) 
highlights the dramatic growth in the popularity of the evaluative style in England and Wales. Brooker (2007) suggests the reason underpinning the increased use in the evaluative style is associated with the high number of mediators practising with a background in law. Menkel-Meadow (1995) suggests that the increased pressure to achieve a settlement outcome on the same day of the mediation (achieve targets) is influencing mediators to adopt the evaluative style in favour over the facilitative style (Golann, 2000; Mulcahy, 2001).

An additional concern regarding the increased use of the evaluative style by mediators is the parties having less control over their mediation (Nolan-Haley, 1998; McDermott and Obar, 2004). This view is further supported by findings in both Canada and the USA where Lowry (2000) highlights that the evaluative style is significantly reducing the parties control with lawyers converting disputes into legal arguments (Lande, 1997; Hart, 1992). Findings in the study undertaken by Clark (2009) into Scottish lawyers' views on mediation reflect similar concerns regarding the reduction in the parties' ability to self-determine their own dispute. However, the increased use of the evaluative style in England and Wales has been highlighted by Genn $(1998 ; 2009)$ as being a significant factor for generating higher numbers of settlement in mediation.

Despite the significant increases in the rate of settlement at mediation, parties are reporting that the use of the evaluative style is failing to provide feelings associated with satisfaction in the process (Genn, 1998; 2009). Negative feelings have been associated with the loss in the parties' ability to self-determine their own dispute (Nolan-Hayley, 2002). Agapiou and Clark (2013) report that it is the client who makes the settlement formally but in practice the decision tends to be driven by the advice of the lawyers, particularly with construction disputes.

There exists a growing body of evidence suggesting that the construction industry is undergoing significant change with its clients seeking 
commercial solutions to their disputes without the use of traditional aggressive and adversarial strategies (Burns, 2013). However, should mediations of the future continue to be dominated by members of the legal profession? Does the style of the construction specialist mediator lead to more satisfying settlements? It is to address these critical questions that this research is being undertaken into construction mediation in England and Wales.

\section{Literature Review}

\subsection{Mediation of construction disputes in England and Wales}

In March 1994 the Lord Chancellor set up an enquiry headed by Lord Woolf to review the Civil Justice System (CJS) in the United Kingdom. Lord Woolf in his report 'Access to Justice' (1996) highlighted the CJS as being too expensive, too slow, lacking equality between powerful and wealthy litigants and under resourced litigants, too uncertain in terms of the length and cost of litigation, too fragmented and too adversarial (Gould et al, 2010). On 26 ${ }^{\text {th }}$ April 1999 the Civil Procedure Rules (CPR) came into force and placed significant emphasis on Alternative Dispute Resolution (ADR) to address the key issues highlighted in Lord Woolf's report. ADR is a broad definition incorporating a variety of processes, which are alternative to the formal litigation system, where the parties prove their arguments in court through an adversarial system of examination, cross examination and challenge (Brooker, 2009).

Around the same time when Lord Woolf was undertaking his review of the CJS, Sir Michael Latham in 1994 produced a report ('Constructing the Team') which identified significant inefficiencies in the construction industry underpinned by adversarial practices (Latham, 1994). The subsequent 'Rethinking Construction' Report (Construction Task Force, 1998) further supported Latham's earlier findings regarding increases in both cost and delays in construction projects due to adversarial practices 
specifically in resolving disputes. The Centre for Effective Dispute Resolution (CEDR) reported in their 2010 and 2012 audits that a significant loss of profit in many construction projects still remains a major issue in the UK construction industry due to adversarial practices in resolving disputes. This view regarding the negative influences of adversarial behaviour in the UK construction industry was also reported by the research project undertaken by Kings College London and the Technology and Construction Court into the use of mediation in construction disputes in England and Wales (Gould et al, 2010).

Following the introduction of the CPR in 1999, specifically rule 44.5 (which requires judges to encourage and assist the parties to use alternate dispute resolution in appropriate cases) the number of disputes being addressed by mediation increased as reported by the Technology Construction Court in their annual reports (Hudson-Tyreman, 2008). However, it was the case of Dunnett $v$ Railtrack plc (2002) in which cost sanctions were applied against a successful party for unreasonably refusing to mediate, that has been reported in the literature as the main catalyst stimulating growth in the use of mediation for resolving construction disputes in England and Wales (Brady, 2009; Brooker, 2009). The status of mediation in resolving commercial disputes has been significantly raised following support by Lord Justice Jackson as emphasised in both his preliminary report (2009) and his final report (2010) in which he addressed the reforms to the costs associated with Civil Litigation. However, Lord Justice Jackson stated that whilst mediation can be an extremely useful and efficient method of resolving disputes, it should not be made compulsory (Jackson, 2010).

\subsection{Mandatory mediation}

Mandatory mediation has been implemented in several jurisdictions including Italy, Romania, North America, Singapore, Canada and Australia 
with the aim of reducing the number of disputes requiring litigation. The mandatory mediation scheme has been reported as significantly increasing mediation activity and encouraging more positive attitudes regarding the use of ADR (Wissler, 2002). Thompson (2004) reports from the courtconnected programmes in the US and Canada that lawyers dominate these mandatory schemes, bringing their own values and practices to the mediation process changing it from a client focused dispute resolution process to an aggressive and adversarial litigation device.

In 1996, judges in the Central London County Court (CLCC) established a pilot mediation scheme for non-family disputes with a value over $£ 3,000$. The scheme's objective was to offer virtually cost-free court-annexed mediation to disputed parties at an early stage in litigation. The scheme's purpose was to promote a swift dispute settlement and reduce legal costs. Professor Dame Genn (1998) reported on the scheme comparing mediated and non-mediated disputes which had achieved a settlement. She observed that in the disputes which had attended mediation they had settled several months earlier than non-mediated cases which had also achieved a settlement, significantly reducing both time and costs for both parties involved. She also observed that those parties which volunteered to attend mediation in good faith had a significantly higher settlement rate than those forced by the court to enter into mediation.

Gaitskell (2005) highlights that the enforcement of mandatory mediation could compromise on the parties' human right to a fair trial, specifically article 6.1 of the Council of Europe's Convention for the Protection of Human Rights and Fundamental Freedoms which states that, everyone is entitled to a fair and public hearing within a reasonable time by an independent and impartial tribunal established in law. The Court of Justice of the European Union (CJEU) put this matter to the test in the case of Alassini v Telecom Italia SpA (2010) and stated that, no contravention of Article 6 of the European Convention on Human Rights had arisen from 
the implementation of compulsory mediation as one is not being forced to settle their dispute in mediation, but rather obliged to attend the mediation session before proceeding to litigation in the attempt to save costs and time (Brooker and Wilkinson, 2010). Lord Phillips (former Lord Chief Justice) further emphasised that the introduction of mandatory mediation to England and Wales would not contravene human rights, as mediation places the responsibility for finding a solution into the disputants' hands and failure by the parties to resolve the dispute would only briefly delay the route to trial (Hudson-Tyreman, 2008). However, Lord Phillips highlighted that there is a big difference between powerful persuasion of the parties to attend mediation in applying costs sanctions for refusal to attend mediation as used in the case of Dunnett $v$ Railtrack plc (2002) and directing the parties to attend compulsory mediation. Sharland (2012) argues against the enforcement of cost sanctions for refusal to attend mediation as this adversely affects the core voluntary principle underpinning mediation.

Agapiou and Clark (2013) reported in their study that a Scottish lawyer commented if mediation is made compulsory then parties can use tactics such as turning up on the day to avoid punishment, but not engage in the process. This view regarding parties using adverse tactics to avoid engaging in the mediation process has been supported by findings in many of the countries where it is mandatory for parties to mediate prior to attending court (Brooker, 2007). Roberts (1992) highlights that in North America there has been an increase in tactics adopted by the lawyers acting for the clients as advocates to undermine the process when engaging in mediation.

This adverse behaviour by lawyers potentially sabotaging the chances of a settlement through mediation has been reported as taking place for several years in England and Wales (Richbell, 2008). Alexander (2006) highlights that the tactics used by lawyers in trying to undermine the 
mediation process include selecting the date for the mediation, so the parties have insufficient time to fully prepare, or alternatively selecting a venue which is as inconvenient as possible.

\subsection{Adjudication}

The introduction of the Housing Grants, Construction and Regeneration Act (HGCRA) in 1996, which provided parties to construction contracts which fall within it a right to refer a dispute or difference to adjudication at any time, has been viewed by Richbell (2008) as a major obstacle to the growth of mediation in the construction industry. Adjudication provides the parties with a cost effective enforceable interim decision (Hibberd and Newman, 1999).

Advocates of adjudication argue the main justification for its use in resolving construction disputes in preference to mediation, is that a decision is guaranteed at the end of the process with minimal disruption to the programme of the project (Meyer, 1993). A study undertaken by Barrett et al (2005) found that adjudication has not proved to be an ideal solution to the issue of dispute resolution in the England and Wales citing poor timescales, ambush and lack of clarity regarding the enforcement of the adjudicator's decision. Therefore, whilst a settlement to the dispute can be guaranteed within 28 or 42 days from the Notice of Referral ( 28 days +14 days extension if required by the adjudicator) there appears to be many more commercial and practical advantages to selecting mediation over adjudication (Gould, 2009).

Hudson-Tyreman (2008) argues that adjudication is simply another adversarial method of dispute resolution in which one party wins and the other party losses. However, mediation is non-adversarial in its nature and seeks to find a solution to the dispute which is acceptable to both parties. Clark (2012) suggests that in mediation each party retains control 
of the negotiations as they are conducted in person with the opportunity to discuss all the issues both in and around the dispute openly, rather than the submission of documents and interpretation of the dispute by a third party. Ter-Haar and Ter- Haar, (2010) argues that resolution of a dispute through mediation provides the parties with a greater feeling of success than by other forms of ADR. Thompson (2004) suggests that resolution by mediation also preserves the business relationship between the parties following the dispute. The value of good business relationships between the parties is critical to influencing the success of construction projects both large and small (Bush, 2002). Good business relationships during a project have been reported to have additional value following project completion, with significant importance in times of a recession (Gould et al, 2010).

\subsection{Accreditation and regulation of mediators}

In the UK no single professional body has overall control for mediator accreditation (Brady, 2009). Arguments for the regulation and accreditation of mediators in the UK are considered as being one of the most controversial topics in the construction industry (Richbell, 2012). The leading voices resisting the move towards formalised accreditation of construction mediators include Dr Karl Mackie (Chief Executive of CEDR) who supports a free market for the evolution of ideas and variety of training approaches (Gould et al, 2010). Gould et al (2010) argue that the practice and number of repeat appointments of mediators as reported in their findings does not indicate that there are poor standards in construction mediation necessitating the need for state regulation.

Arguments against mediator regulation are frequently based on market demand, which it is suggested controls development and the use of mediation (Moore, 2014). Alexander (2006) states that allowing market demand and mediators a free rein results in an abundance of different 
approaches about which consumers may not always be sufficiently informed. Lowry (2000) suggests that when parties lack information about construction mediation they can feel threatened when the mediator takes an evaluative stance or disappointed if the mediator remains facilitative, which can be avoided if all parties enter the process with the same set of expectations and understandings. Brooker (2007) suggests that if mediation is to achieve its maximum potential in England and Wales, choice of mediator style must be addressed by basing selection on information formed on the basis of transparent standards of practice and training. This view regarding the repeat appointment by mediators as suggested by Gould et al (2010) is rather a simplistic observation to explain how satisfied parties are with the performance of their mediator and outcome of the settlement (Richbell, 2008). Menkel-Meadow (1995) emphasis that mediators should be accountable, especially in cases when users are vulnerable or there is an unequal power difference.

\subsection{European initiatives on mediation practice}

In 2004 the European Union (EU) introduced a mediator code as a voluntary set of broadly drawn principles to which mediators and organisations can commit (Brady, 2009). In the preamble, the code recognises that providers of mediation may wish to develop more detailed codes which they have adapted to their specific context or the types of mediation services they offer. The text of the EU code does not explicate self-determination or informed consent, but the mediator is required to ensure that the parties understand the characteristics of the mediation process and the role of the mediator and the parties in it and must also make sure that all parties have adequate opportunities to be involved in the process. Brooker and Wilkinson (2010) note that the EU Code is silent on mediator style, but mediators are required to conduct the mediation in an appropriate manner taking into account the circumstances of the case, including possible imbalances of power and any wishes the parties may 
express. The EU Code supports market choice by stating that parties are free to agree with the mediator by reference to a set of rules or otherwise on the manner in which the mediation is to be conducted (Brady, 2009; Gould et al 2010).

An EU Directive came into force in 2008 which requires each member state to put in place a predictable legal framework for mediation in cross border disputes (Brady, 2009; Brooker and Wilkinson, 2010). Each member state should encourage the development and adherence to voluntary codes of practice; provide effective quality control mechanisms, foster initial and further training of mediators. Like the EU Code, the directive does not delineate the approach a mediator should use nor does it highlight self-determination or informed consent, but section 13 supports these principles by stating that, the parties are themselves in charge of the process and may organise it as they wish and terminate at any time. Thus the directive supports a market based approach by indicating that the mechanism should aim at preserving the flexibility of the mediation and the autonomy of the parties (Brady, 2009 and Gould et al 2010).

The International Mediators Institute (IMI) has taken the initiative to introduce an international mediator competency standard and its mission is to develop mediation into a free-standing profession over all fields worldwide which is based on high competency and ethical standards and to ensure transparency via profiles including mandatory information and a summary of feedback by prior users. The IMI code of conduct (International Mediators Institute, 2014) requires mediators to explain the process to the parties and their advisors and be satisfied that they consent to the process used. There is a professional conduct assessment process which parties can activate if they believe there has been a lack of compliance with the code of conduct. Accredited mediators add their profiles to a searchable database which must include information about 
their experience, style, code of conduct, complaints process, professional indemnity and feedback. Mediation's credibility relies on the separate professional standing of its practitioners and should remain a selfregulating system (Macfarlane, 2002a; McDermott and Obar, 2004).

One of the major issues raised by Brooker (2011) concerns the lack of prominence given towards party self-determination in the EU mediators' code in contrast to other countries and international organisations. Selfdetermination is the underlying principle in mediation and sets mediation apart from other forms of ADR. However, the use of the evaluative style is considered as undermining the parties' ability to self-determine their own dispute. Richbell (2008) argues that providers of construction mediators in England and Wales are not going far enough with promoting selfdetermination and providing potential users with sufficient information to enable them to make informed decisions regarding the process and mediator's style in their marketing and advertising. Brooker (2011) advocates that mediators should be held to an ethical duty when marketing and advertising their skills of a mediator ensuring transparency to allow consumers greater levels of informed consent without restricting mediators style or innovation.

\subsection{Mediation styles}

The analysis of mediator styles was stimulated by Riskin's (1996) mediation grid with one continuum representing the mediator's notion of the mediator's role anchored by facilitative and evaluative styles. Riskin (2003) subsequently refined his system proposing a "New New Grid System" dividing mediation decision making into three categories: substantive, procedural and meta-procedural.

The two main styles used in the mediation of construction disputes in England and Wales are facilitative and evaluative (Brooker 2007; Gould et 
al, 2010). In facilitative practice, mediators use their skills of listening, questioning and reframing to help the parties communicate and reach their own settlement outcomes. The evaluative mediator differs in their style by offering information and opinions on the substance of the dispute. Interventions by the evaluative mediator might include imparting a view regarding the merits of the case or particular issues, assessing the strength and weaknesses of presented cases, making predictions about a court outcome or providing settlement proposals with the parties consent. In the event that the parties fail to reach a settlement the evaluative mediator may also give their recommendation (Golann, 2000).

Lowry (2000; Nolan-Hayley, 2002; Noce et al, 2002; McDermott and Obar 2004; Richbell, 2008) all strongly advocate the use of the facilitative style of mediation in preference to the evaluative style suggesting that the evaluative style undermines the parties' ability to self-determine their own dispute. The attributes of self-determination include the parties actively participating in the process, controlling the decision making, creating settlement outcomes and deciding whether to settle or not. The ability for the parties to self-determine is viewed by Alfini (2008) to be the single core value upon which mediation is based and which differentiates mediation from other forms of ADR.

However, Dolder (2004) argues that possibly the most significant difference between the styles is the importance of settlement in each case. The increased use of the evaluative style in England and Wales has been emphasised by Genn $(1998 ; 2009)$ as being an important factor creating greater numbers of settlement in mediation. Similarly, Stipanowich's (1996) research demonstrated that mediations settled more frequently when US construction mediators stated their opinions.

\subsection{Mediation in the USA}


In North America empirical evidence shows significant growth in the number of disputes in the construction industry being resolved by mediation following the implementation of court-schemes (Welsh, 2001). In conjunction with the expansion of mediation in resolving construction disputes is the growth in the number of mediators reported using evaluative techniques with lawyers dominating the process (Welsh, 2001; Tronson 2006). In contrast to the increase in the growth of evaluative mediator style in the USA is the emphasis which is placed on informed self-determination by the parties. The importance of self-determination is considered by the American Arbitration Association (which sets the standard of mediation practice and other forms of ADR in the American Construction industry) as being integral to mediation because this principle guarantees fairness and strongly contributes to party satisfaction. However, there seems to be a big discrepancy between what is recommended by the American Arbitration Association (AAA) and what is actually happening in the commercial setting of mediation in the American construction industry (Strasser and Randolph 2004; Wissler 2002).

The escalation of US lawyers using evaluative techniques in which the parties have minimal involvement in the mediation process is reported to giving rise to a number of concerns in academic circles (Lande, 1997; Hensler 2002). Nolan-Hayley (2002) argues that the growth in the use of the evaluative style is undermining the ability of the parties to selfdetermine their own dispute and is contradicting what is advocated by the AAA for mediation in the USA. But, with increased pressure to resolve a dispute quickly and cheaply, it appears from reports in the literature that the evaluative style is going to continue to increase in use by mediators for construction disputes in the USA (Welsh, 2001). Critics of the evaluative style warn of the inherent dangers of alienating or losing the trust of the parties when the mediator gives advice or offers opinions on the strength of a case (Hart, 1992). This view is further supported by 
Nolan-Hayley (1998) who suggests that if the mediator makes a court prediction, this can distort settlement towards that outcome.

Brooker (2011) reports that some lawyers in North America are viewing attending mediation not as a client focussed dispute resolution process, but as the opportunity to test the strengths and weakness of their case against the other parties prior to litigation. McDermott and Obar (2004) highlight how lawyers are trying to dominate the mediation process, behaving in an adversarial manner and only focusing on achieving a financial settlement and ignoring the possibility of creative outcomes which focus on the interests of the parties. Meyer and Leathes (2008) report that following the institutionalising of mediation through courtconnected schemes in both USA and Canada there has been a significant shift moving away from the purist ideal of facilitating the parties' interests and autonomy, towards facilitating the quantitative objectives of the courts and lawyers. This court-connected scheme has led to a significant increase in the use of $A D R$, but also an increase in other problems relating, not only to the outcomes achieved by mediation but the very nature of the process (Wissler, 2002).

\subsection{Study of Scottish lawyers}

Findings in the study undertaken by Agapiou and Clarke (2012) of Scottish Lawyers reflect similar concerns to those in the USA regarding the reduction in the parties' ability to self-determine their own dispute in mediation. They state that, it is the client who makes the settlement formally and lawyers acting as advocates for the parties can only give advice, but in practice the final decision tends to be driven by the advice of the lawyers, particularly with construction disputes. This view is further supported by the findings reported in Brooker (2007) who states that, many disputes in the construction industry are complex and financially large and when these conditions prevail, parties are likely to seek legal 
advice before embarking on mediation and during the process. The involvement of legal personnel in mediation significantly reduces the parties control over self-determination when lawyers acting as advocates start converting disputes into legal arguments. Professor Dame Genn (1998) reported that the highest number of settled mediations in the CLCC pilot mediation scheme (72\%) was achieved in the absence of any legal representatives. Critics of the evaluative style also suggest that mediators are not trained adequately for decision-making functions and the safeguards afforded in the formal systems such as litigation, arbitration or statutory adjudication are not present (Hibberd and Newman, 1999).

The study undertaken by Agapiou and Clark (2012) also highlighted that the interviewees expressed a preference for mediators to act more proactively rather than reactively in their approach, and rather more interventionist and directive in favour over the facilitative style of mediation. This reflects mediation practices observed in the USA where there appears to be a greater preference in the use of the evaluative style of mediation. This increase in the use of the evaluative style is considered to be driven by the need to have the dispute resolved quickly. However, the benefits of having the dispute resolved quicker through the use of evaluative techniques are viewed by the those individuals who advocate the support for the use of the facilitative style as diluting the true values underpinning mediation as a vehicle for dispute resolution and where by the parties lose their ability to self-determine their own dispute (NolanHaley, 2002). The use of the evaluative style is suggested as having the benefit of resolving the dispute quicker, but at the expense that the parties are left feeling less satisfied with the outcome (Golann, 2000). This increase in the use of the evaluative style has also been associated with the increase in the costs for the mediation of construction disputes in the USA (Noce et al, 2002). 
Stipanowich (1996) provides evidence which shows that when US construction mediators expressed their opinions on pertinent facts or law, mediation settled more often than when they did not give their views, with $71 \%$ of mediations reaching full or partial settlement when mediators employed these evaluative techniques, compared to $55 \%$ when they did not. Conversely it is noted in Welsh (2001) that mediator views did not statistically affect the outcome for construction disputes. The lack of empirical data regarding the effectiveness of the mediator's style in reaching a settlement for the mediation of construction disputes means its effect remains inconclusive (Brooker, 2011). However, the critical factor when selecting mediation for the resolution of construction disputes is the appropriate selection of the mediator, in providing the actions and activities the parties wish their mediator to carry out, in providing their desired outcome (Moore, 2014).

\subsection{English lawyers mediating construction disputes}

Research indicates that the legal professions dominate construction mediation in England and Wales with lawyers similar to the USA reported to be positioning themselves either as mediators or within the process as advisors representing their clients' cases (Gould, 2009; Brooker and Wilkinson, 2010). This view is supported by evidence from CEDR's audit (2010) which suggest that $81 \%$ of practising mediators in England and Wales come from a legal background. These findings are also replicated in the Technology and Construction Court (TCC) survey where the majority of mediations were undertaken by lawyers $(41 \%$ by solicitors, $34 \%$ by barristers, $7 \%$ by judges) and only $16 \%$ by other construction professionals (Gould et al, 2010). Both the CEDR audit and TCC survey suggest that as parties become more familiar with the process of mediation, they avoid appointing bodies and prefer to make direct appointments with the mediators they have used before or from recommendations (Gould et al, 2010). The TCC survey found only $20 \%$ of 
recorded mediations went through ADR providers and that a small core of legal experts operate in this forum.

The Bar Council reports increases in the number of barristers training as mediators and that their skills make them particularly apt mediators (Bar Council, 2014). However, some of these skills of the barrister are evaluative in their nature and include evaluating strengths and weakness and advising on likely outcomes (Golann, 2000). McDermott and Obar (2004) suggest that the influence of the legal professions is associated with a rise in the use of evaluative mediator style and an increase in the adversarial behaviour in construction mediation in England and Wales. Mulcahy (2001) highlights that lawyers should safeguard selfdetermination by raising their client's awareness of mediator style which would support a bone fide choice based on informed consent.

Surveys undertaken by CEDR and the TCC clearly show that the majority of English and Welsh mediations are undertaken by members of the law profession (Brooker, 2007; Gould et al, 2010). However, the views of Scottish contractors and sub-contractors revealed a strong preference for mediators with specialist construction industry expertise, with few stating that mediators should be lawyers (Agapiou and Clark, 2012). Interviewees in the same study reported that greater emphasis should be placed on the mediators experience and understanding regarding the commercial issues of the dispute than their knowledge of the law. Several subjects reported in the same study of Scottish lawyers that legal training could be an impediment and that a different mind-set was required to be an effective mediator. This view is shared by several authors in the literature including (Lowry, 2000; Nolan-Hayley, 2002; Richbell, 2012) who suggests that, although training and education for lawyers in becoming mediators are useful tools to help eradicate their adversarial nature, previous experience tends to have a more profound effect on their attitude when mediating. 


\subsection{Summary}

Research undertaken by both CEDR and the TCC suggest that the majority of mediations in England and Wales are being undertaken by members of the legal profession. Concerns have been raised regarding the suitability of lawyers performing the duties of a mediator in construction disputes due to the potential adverse influence of their legal training and experiences in working in an adversarial environment both in England and Wales and in North America.

The increased use of mediation in resolving construction disputes is strongly supported by Lord Justice Jackson. However, should lawyers continue to dominate construction mediation in England and Wales or do the attributes of construction specialists better reflect the needs in mediating satisfying solutions to disputes in the construction industry? The aim of this research is to explore the differences that may exist between a lawyer mediator and non-lawyer mediator in construction disputes. In addition, mandatory mediation, the role of advisors/advocates, governance and the future of mediation were explored.

\subsection{Methodology}

The starting point for all research projects should always be a review of the literature (Creswell, 2013).

The issue the researcher focused on investigating, due to a lack of available knowledge in the literature, concerned the different attributes that a lawyer and construction specialist may utilise when performing their duties as a mediator, and the influence (if any) of their previous professional backgrounds on their behaviour as a mediator.

The main justification underpinning the selection of a qualitative approach in preference to quantitative in the research design is to acquire a greater level of understanding from the respondents' perspective. According to 
Richards (2009) the nature of qualitative research makes it more suitable than quantitative for addressing the aims and objectives of this specific study which focuses on the meanings held by the individuals acquired through different events and experiences in order to gain new insights, discover new ideas and increase our knowledge. The nature of quantitative research differs to qualitative in that does not recognise the individuality of human beings, often grouping people into set categories which can lead to over simplification of human nature (Morse, 1994).

The justification in selecting phenomenology in preference to the other alternatives within qualitative research is because phenomenology is concerned with the individual's experience, closely reflecting the aims and objectives (Bryman and Burgess, 1994). Phenomenology research seeks to describe, rather than explain and is particularly effective at describing the experiences and perceptions of individuals from their own perspectives and also has the ability to challenge both structural and normative assumptions (Richards, 2009).

The original sample population was composed of qualified mediators with a professional background either in law or the construction industry with a minimum of two years' experience following successful completion or qualification from an organised body i.e. CEDR or the RICS working within the West Midlands. The minimum of ten participants, as recommended by Creswell (2013) for a phenomenology study was planned. However, to achieve this sample size, the geographical boundary was extended to throughout England.

One of the major challenges faced by all researchers is acquiring suitable candidates to participate in their study (Sapsford et al., 2006). By implementing a strategy of attending events held by the Society of Construction Law and the Association of Midland and Northern Mediators, the researcher was able to build up a network of willing participants that work within the construction industry. 
There are several tools which can be utilised in the collection of qualitative data including observations, questionnaires and interviews (Strauss and Corbin, 1998). Interviews are often considered as having a significantly higher potential at producing data higher in quality in preference to questionnaires or observations (Bryman and Burgess, 1994). The most appropriate method of data collection which reflects the issues highlighted during the literature review and used in this study was interviews.

The interviews were undertaken over the telephone. The major advantage regarding the collection of data from using a telephone interview is that the process is very time efficient for both the interviewer and the interviewee.

Semi structured questions were used because it maintained a degree of consistency throughout all the interviews, but also provided the participant with a greater degree of latitude to respond to the questions in the ways that seem sensible to them (Thody, 2006). Semi-structured interviews also provided the interviewer with greater scope to pursue other avenues of interest discovered through the interview (Morse, 1994). The questions were sent seven days in advance of the interviews to provide the opportunity for the respondent to consider in greater depth their reply to the question (Sapsford et al., 2006).

Thematic Analysis (TA) was the most appropriate choice for analysing the data in this phenomenology study because it focuses on the human experience subjectively and aims to identify implicit and explicit ideas that exist within the data (Denz, 2003). TA emphasises the participant's perceptions, feelings and experiences as the paramount object of the study (Patton, 1990). The major advantage associated with this approach is that it provides flexibility allowing for categories to emerge from the data (Sapsford et al., 2006). 
Following the collection of the data into an audio file it was transcribed by an independent third party. The ten interviews transcribed averaged between thirty and sixty minutes.

The development of computer software has been shown as having the potential to significantly reduce the time researchers spend forming links in data analysis. However, it is the design and use of the parameters which are critical to maximising the quality from the data collected (Richards, 2009). The researcher selected the software NVivo 9.2 to manage the data. The NVivo software was excellent in generating additional emergent categories and establishing the relationships and links between the categories across all the data provided by the interviewees.

When designing research, attention must always be directed towards ethical issues (Bell, 2005). These issues include adhering to ethical standardswhich promote the aims of the research such as knowledge, truth and avoidance of error (Mauthner et al., 2002). Research often involves a great deal of cooperation among many different people in different disciplines and institutions, and the adoption of ethical standards promotes the core values that are essential to support collaborative work including trust, accountability, mutual respect and fairness (Morse, 1994). Therefore, prior to any interviews being undertaken the researcher ensured that university ethical approval was obtained and interview consent forms had been signed and returned. All interviews were to be reported anonymously.

It is important to highlight that mediations are undertaken in a private setting and access to information discussed in mediations would be strictly confidential. Therefore, the researcher reinforced that the aim of the study is to focus on the behaviour and attributes of the mediator and the researcher avoided discussing specific details associated with any client's case, past or present.

\section{Results and Discussion}




\subsection{Introduction}

This section presents the results and discusses the findings from the semistructured interviews conducted with ten mediators working within the construction industry in England and Wales. The data is critically analysed and compared and contrasted with the literature.

\subsection{Experience and professional background of the mediators interviewed}

The interviewees all confirmed that they met the criteria for this research by being qualified by an accredited body and practising in the construction industry for a minimum of two years. The background of the mediators was a mixture of lawyer mediators (LM) and non-lawyer mediators (N-LM) in the ratio of 6/4. The experience of the mediators practising in the construction industry ranged from three to twenty two years.

Table 1: Experience and professional background of the mediators interviewed.

\begin{tabular}{|c|c|c|c|c|c|c|c|}
\hline \multicolumn{7}{|c|}{} & \multicolumn{3}{l|}{$\begin{array}{l}\text { Experience mediating construction } \\
\text { disputes (years) }\end{array}$} & \multicolumn{2}{l|}{ Background } \\
\hline Interviewee & $<4$ & $5-9$ & $\begin{array}{c}10- \\
14\end{array}$ & $\begin{array}{c}15- \\
19\end{array}$ & $>20$ & $\begin{array}{c}\text { No Law } \\
\text { (N-LM) }\end{array}$ & $\begin{array}{c}\text { Law } \\
\text { (LM) }\end{array}$ \\
\hline $\begin{array}{c}1 \text { (civil } \\
\text { engineer) }\end{array}$ & & 1 & & & & 1 & \\
\hline 2 (solicitor) & & 1 & & & & & 1 \\
\hline 3 (solicitor) & & & & & 1 & & 1 \\
\hline $\begin{array}{c}4 \text { (civil } \\
\text { engineer) }\end{array}$ & & & & & & 1 & \\
\hline 5 (surveyor) & & & & & 1 & 1 & 1 \\
\hline $\begin{array}{c}6 \text { (construction } \\
\text { manager) }\end{array}$ & 1 & & & & & 1 & \\
\hline 7 (lawyer) & & & & 1 & & & 1 \\
\hline 8 (solicitor) & & & 1 & & & & 1 \\
\hline
\end{tabular}




\begin{tabular}{|c|l|l|l|l|l|l|l|}
9 (barrister) & & & & 1 & & & 1 \\
\hline 10 (solicitor) & & & & & 1 & & 1 \\
\hline Total & 1 & 2 & 1 & 3 & 3 & 4 & 6 \\
\hline
\end{tabular}

\subsection{How mediators are invited to mediate disputes}

Mediators from both groups reported that work was acquired from a variety of sources including nominating bodies such as the RICS, solicitors, networking events such as the Society of Construction Law and ADR panels. Interviewee 2 responded "They are either brought to me through a nominating body, or I get approached directly by a firm of solicitors." Table 2 illustrates that the majority of mediators work is supplied through solicitors followed by ADR panels.

Table 2: Mechanisms by which mediators are invited to mediate over disputes

\begin{tabular}{|l|c|}
\hline $\begin{array}{l}\text { Access to mediation } \\
\text { invitations }\end{array}$ & $\begin{array}{c}\text { Number of references made in } \\
\text { the interview }\end{array}$ \\
\hline ADR - Panels & 6 \\
\hline Direct from the parties & 2 \\
\hline From solicitors & 8 \\
\hline Networking events & 2 \\
\hline Nominating bodies & 2 \\
\hline Marketing - websites & 1 \\
\hline
\end{tabular}

\subsection{Mediators' professional background}

All interviewees with a legal background expressed the similar view that they have had previous experience of representing both sides to a dispute. The LM group further suggested this specific experience placed them in a uniquely advantageous position over the N-LM in having the knowledge and ability when advising both parties on the potential consequences regarding the escalation of costs and time, if the dispute is 
not resolved during the mediation. Interviewee 2 explained "As a solicitor, I have experience performing the role as supporting the defendant and claimant and try highlighting the risks and costs that are involved if the dispute is not settled and continues along to adjudication or litigation." Mediators with a law background also expressed the advantage of their experience as a lawyer in identifying the strengths and weaknesses of each party's case and their ability to undertake a risk analysis. The LM group also suggested that lawyers work full time in an environment which is often hostile and adversarial requiring skills of conflict management and this experience makes their background ideal for being an effective mediator. Interviewee 2 argued that "I think lawyers have significantly more experience at managing hostile environments which makes them very effective mediators." Agapiou and Clark (2013) highlight that although training and education for lawyers in becoming mediators are useful tools to help eradicate their adversarial nature; previous experience tends to have a more profound effect on their attitude when mediating, especially in times of impasse.

$\mathrm{N}$-LM suggested that they had all experienced similar disputes working in commercial construction and therefore are significantly better placed than LM in understanding the commercial constraints which often lead to the development of the dispute. Interviewee 6 argued "I have over 15 years' experience working in construction management and understand the problems faced by both contractor and the client regarding the pressure and constraints to get projects completed on time and budget." This specific experience was suggested by the N-LM group as providing them with a greater sense of empathy than the LM group. The N-LM group also reported a different view to LM concerning an awareness of the impact the dispute could have on the team dynamics of the project and future working relationships between the parties. Interviewee 5 explained "These problems go beyond the financial and include the loss of time and focus on the parties' core business and future opportunities to work together." 
Both groups reported that differences do exist between the two professional backgrounds and further suggested that the mediator's professional background may influence the individual mediator's behaviour. However, the extent to which their professional background influences their role as a mediator is impossible to state with any degree of certainty as neither party was willing to dis-credit the other profession.

\subsection{Preferred style of mediation for construction disputes}

$5 / 6$ of the mediators from a legal background supported the use of the evaluative style, with Interviewee 2 commenting "I try to stick with the evaluative style", in comparison to the non-law mediators where only $1 / 4$ supported the use of the evaluative style.

The majority of N-LM (3/4) did not support the use of the evaluative style but only the facilitative style, suggesting the loss of self-determination by the parties when the evaluative style is used, significantly undermines the philosophy of mediation. Interviewee 6 reasoned "I'm not evaluative at all. Parties especially during an impasse will look to the mediator for an answer, but I only act in a facilitative way and do not give my opinion. The settlement needs to be made by the parties themselves." 3/4 mediators from the N-LM group all commented that LM are often too quick to utilise the evaluative style when faced with challenges such as an impasse in order to achieve a settlement on the day.

The majority of LM (5/6) suggested that the use of the evaluative style is acceptable in order to keep the parties communicating, rather than allowing the parties to walk away from the mediation. However, Interviewee 2 cautioned that "I think it is important that the mediator informs both parties that in advance of mediation the evaluative style may be used in the event of an impasse to keep the mediation on track." The $\mathrm{N}$-LM group commented that parties who agreed a settlement under the pressure exerted by the mediator using the evaluative style increased the risk of the settlement collapsing shortly after leaving the mediation and 
the potential for the relationship between the parties being destroyed. The $\mathrm{N}$-LM group also suggested that on those occasions when the mediation does not produce a settlement on the day, both parties may still feel satisfied in the process undertaken and may benefit from participating in the mediation with the outcome of stronger lines of communication, which may in turn lead to a delayed settlement or better working relationship in the future.

5/6 LM highlighted that an unsatisfactory settlement achieved in mediation is much better than the dispute escalating to court regardless of the style used, providing the mediator is experienced and legally qualified to offer their opinion. However, the LM group expressed their concern about N-LM working beyond their 'brief' if they use the evaluative style. Mediators from both groups reported that when undergoing their training in England and Wales they were strongly encouraged to use the facilitative style by organisations such as CEDR and the RICS. Interviewee 7 explained "Most mediators in this country are trained on a facilitative method". Concern was also expressed from both groups that those mediators with no formal legal training should not be using the evaluative style and offering their opinion on the legal merits of their case in the event the dispute escalates and proceeds to court, as this approach carries the risk of exposure of the N-LM to a charge of professional negligence.

There is growing concern regarding the increased popularity in the use of the evaluative style in construction mediation in England and Wales, which is being driven by lawyer mediators (Richbell, 2012). The issues raised by Gould (2009) and Brooker \& Wilkinson (2010) regarding the growth in the use of the evaluative style in the UK construction industry concern the potential reduction in the parties ability to self-determine their own dispute. 
The pressure to achieve a settlement in mediation including the use of the evaluative style should be strongly discouraged by all mediators in the construction industry to avoid the risk of both parties feeling unsatisfied with the process, leading to regrets concerning the terms of the agreement following the mediation (Bowie, 2004). This view was strongly supported by all interviewees in the N-LM group. However, 4/6 interviewees from the LM group reported that, achieving a settlement on the day of mediation as being more important than the feelings of satisfaction experienced by the parties following the mediation.

Richbell (2012) argues that providers of construction mediators in England and Wales i.e. the training bodies for mediators (RICS \& CEDR) are not going far enough with promoting self-determination. However, interviewees from both groups reported that when undergoing their training by the RICS or CEDR they were all strongly encouraged to use the facilitative style in preference to the evaluative style. Richbell (2012) further suggests that some mediators are not providing sufficient information in their advertising material to enable parties to make informed decisions regarding the mediators preferred style of mediation and the implications. Mediators from both groups strongly supported the same view that all clients should be made aware in advance of the mediation of the approach to be used by the mediator, including the implications of adopting the two different styles to avoid confusion or disappointment on the day.

\subsection{Introduction of mandatory mediation into the UK construction industry?}

Support of mandatory mediation by $3 / 10$ of the mediators was because the mediators believed the process of mediation is effective to manage all types of disputes in construction mediation and could easily be inserted into a clause of the contract. Interviewee 5 argued "I'd like to see it written straight into construction contracts ... I think it would be a real 
asset." However, 7/10 mediators strongly disagreed with the introduction of mandatory mediation into the construction industry because mediation only truly works when the parties volunteer to enter into the process.

The interviewees also reported concern that the potential pressure exerted by a third party such as a regulatory body to attend mediation may reduce the number of disputes being litigated, but at the expense of reducing client satisfaction and the settlements dissolving away before being legally formalised, leading to further polarisation of the parties. This finding supports a long standing view of mandatory mediation such as that expressed by Genn (1998) against the enforcement of mediation following her observations from the pilot study into court-annexed mediations undertaken at the Central London County Court in which a significantly higher settlement rate of disputes were achieved for those disputes who volunteered to attend mediation, than for those parties who were forced by the court to enter into mediation.

The seven interviewees also expressed concern about the additional pressure placed on the mediator to overcome the obstacles of noncooperation and the breakdown in communication by the parties if being forced to attend mediation. The phrase "you can take a horse to water, but you can't make him drink" was used by almost all of the seven interviewees opposing mandatory mediation in the construction industry. The use of cost sanctions following the case of Dunnett $v$ Railtrack plc (2002) was regarded by the majority of interviewees as being sufficient in providing the appropriate level of encouragement for disputes in the construction industry to attend mediation without making mediation mandatory.

\subsection{The role of advocates/advisors (A/A) in mediation}

Both groups highlighted the importance for both parties' $A / A$ to invest time in advance of the mediation. Interviewee 2 argued that "Preparation by the advocates is important both in undertaking the paperwork and 
educating the parties on the procedures on the day." Preparation by the A/A should go beyond the formalities of the day with sufficient time being invested in educating the parties in their use of language both verbal and non-verbal to create a co-operative environment (Nair, 2014).

One of the biggest obstacles to achieving a settlement at mediation reported by the N-LM group is the influence of barristers' behaviour when acting as advocates. The N-LM group further reported experiences of barristers attempting to control the mediation environment through opening statements and unnecessary attention being focused on details of law turning a co-operative environment into an adversarial environment. Interviewee 5 complained that "Barristers definitely influence, control and sadly sometimes sabotage the mediation." No interviewees from the LM group reported experiencing any challenge to their position during mediation from barristers when acting in the role of $A / A$.

The interviewees from the N-LM group did highlight a significant difference between the behaviour of solicitors in the $A / A$ role to the behaviour of barristers. The N-LM suggested that their experience of solicitors acting in the role of $A / A$ were very positive, including preparing the parties with sufficient knowledge concerning the procedures and format on the day of mediation and no reports of challenges threatening of undermining the $\mathrm{N}$ LM position of leader of the mediation process.

One of the secondary advantages highlighted by both groups in the use of solicitors attending the mediation as $A / A$ is that they are able to formalise the settlement legally on the same day, allowing both parties to move forwards. Interviewee 6 commented "If there are lawyers involved, which I often prefer there are because it helps towards the end, if things are successful, they can pull up legal documents, whereas I don't do that" However, it was reported by a few interviewees that the language and formatting in the settlement agreement should be clear and transparent to avoid any additional conflict. 
In the study undertaken by Agapiou and Clark (2013) into views held by Scottish Lawyers regarding mediation in the construction industry, several of the lawyers similarly expressed concern regarding the influence of the parties advocates/advisors in the final decision-making process of the settlement.

\subsection{A single governing body for mediation in the UK construction industry?}

There was strong support ( $8 / 10$ interviewees) for a single governing body to manage both training and regulation of mediation within the construction industry. The reasons reported across both groups ranged from the standardisation of mediator training to a single code of professional conduct. Interviewee 7 explained "The Civil Mediation Council ... attempts to achieve standardisation in training and professional conduct across the industry". However, two of the ten interviewees suggested that having more than one governing body promotes healthy competition.

\subsection{The future of mediation in the UK construction industry}

Mediators from both groups reported that mediation will grow within the construction industry in the next five years due to the support from the Civil Justice System, value for money, parties' positive experiences with using mediation and disappointment with other forms of ADR. Interviewee 3 reported "Currently the number of trained mediators outweighs the number of mediations, but mediation will definitely continue to grow in popularity especially from those parties who have had a positive experience from using it. The government is also strongly encouraging the construction industries to consider mediation early in the lifecycle of disputes to avoid escalating costs and reduce the demand for courts." However, some interviewees suggested that the speed of growth of mediation is restricted by the adversarial nature that still remains within the construction industry. Both groups of mediators reported that 
significantly more needs to be invested in promoting and advertising mediation as an alternative to litigation and other forms of ADR.

One of the major issues raised by all the N-LM and $2 / 6$ of the LM concerned job security following training as a mediator. Interviewees reported that many law colleges and bar practicing schools are preparing their students in the skills of commercial mediation.

Statistics provided by CEDR and the TCC clearly show that the majority of mediators working in the construction industry in England and Wales are members of the law profession (Brooker, 2007; Gould et al, 2010). Securing work was considered to be a major obstacle for newly qualified mediators especially those mediators without a legal background and with limited contact with solicitors. Additional effort was also being undertaken by most of the N-LM in their marketing and advertising, including social networking by attending events and conferences by organisations such as the Society of Construction Law in order to compete for work with LM. Interviewee 6 commented that mediators who attended the same training course, but with a law background acquired significantly more work more easily than he had without a law background.

It would appear that competition for employment as a mediator in the construction industry is growing more challenging with the development of mediator awareness in law schools impacting especially on N-LM (Burns, 2013). This imbalance in the ratio of $L M$ to $N$-LM that exists in the construction industry will continue to remain unless the construction industry addresses the issue (Richbell, 2012).

\section{Conclusions}

The literature highlighted that legal professions dominate construction mediation in both England and Wales with lawyers reported to be positioning themselves either as mediators or within the process as advisors representing clients' cases (Gould, 2009; Brooker, 2007; 2011). 
Richbell (2012) suggests that the majority of mediators are selected on behalf of the parties by their Advisors/Advocates (A/A) who are often lawyers resulting in the recruitment of lawyer mediators.

The major difference in the practice of mediation performed by LM and $\mathrm{N}$ LM as confirmed by the ten interviews is the predominant use by LM of the evaluative style to increase the prospects of achieving a settlement in an attempt to reduce the risk of the dispute escalating into litigation. The interviewees from the LM group reported that the achievement of an unsatisfactory settlement in mediation through the use of the evaluative style is significantly better than the dispute escalating to litigation with the potential for increased costs and stress experienced by both parties.

Interviewees from the N-LM strongly disagreed with the use of the evaluative style in construction mediation and disregarded the claims concerning its effectiveness in assisting the parties to generate a settlement, due to its potential to erode the degree of self-determination and reduce the level of satisfaction experienced by the parties as reported by Lande (1997) and Lowry (2000).

The consensus of the six interviewees from the LM group suggests that the use of the evaluative style is acceptable in construction mediation providing it is undertaken only by those mediators with sufficient legal qualification and experience. The use of the evaluative style regardless of experience and qualification of the mediator, in the opinion of the interviewees in the N-LM category, is to be avoided due to the risk of impinging on the parties' ability to self-determine their own dispute, which is the principle underpinning a successful settlement in mediation.

It can therefore be concluded in line with Richbell (2012) that experiences acquired by individuals when working in different disciplines within the 
construction industry strongly influences the way they think and behave as mediators when mediating disputes.

The consensus of the interviewees from a legal background (LM) was that their professional background in law has provided them with greater levels of experience in working in adversarial environments than the N-LM. In their view, this specific experience involving managing environments which are adversarial has assisted them to become very skilled in conflict management and being more effective in mediating construction disputes.

The consensus of the interviewees from the N-LM group was that their commercial experience in the construction industry has facilitated the development of a deeper sense of empathy with their parties and a greater understanding of the development and fallout following a dispute.

The experience that interviewees from the N-LM group reported concerning the behaviour of barristers acting in the role of the parties $A / A$ is significantly different to those reported by LM. Interviewees from the NLM group reported several experiences where barristers had tried to dominate and control the mediation process. However, these experiences were never reported by any interviewees from the LM group. These reports by N-LM reflect findings from Agapiou and Clark (2011) and Richbell (2012) who suggest that barristers have difficulty in relinquishing control in mediations, especially to those mediators who are not as equally legally qualified. Findings in the study undertaken by Agapiou and Clark (2013) also suggest that the ability of the parties to self-determine their own dispute is being further eroded by the influence of the parties' $A / A$.

A reason suggested for the low ratio of N-LM to LM concerns the influence of the parties A/A in the selection of the mediator. Richbell (2012) and Burns (2013) both argue that unless the construction industry undertakes drastic measures to educate and inform potential users of mediation and 
those individuals/organisations responsible for mediator selection on behalf of their clients the ratio of N-LM to LM will remain. This situation regarding the disproportionate ratio of LM to N-LM has the potential to discourage potential N-LM undertaking mediator training, leading to a loss to mediation practice of the commercial and technical expertise of N-LMs as well as the evaluative styles they promote, and ultimately a loss of choice for users of mediation (Nolan-Hayley, 2002; Alexander, 2006; Brady, 2009).

These findings have significant practical implications for mediation practice. Firstly, given the differences in style possible under different mediators and the potential for a disconnect between the expectations of disputing parties and mediators, it is essential for parties or their advisors/advocates to vet mediators' credentials more closely with attention paid to their preferred styles and the likely impact on the mediation prior to their appointment. Parties also need to explain their preferred outcomes more clearly to mediators. In this regard, terms of engagement of mediators need to be drafted to include provisions on mediation styles. Conversely mediators must check expectations of parties more thoroughly including preferred outcomes and reflect this in the styles they adopt. The extent to which mediators of a particular background can switch between styles is however an issue that requires research. The fact, as reveal by this study, that professional background is a powerful determinant of mediation style implies that key training bodies like CEDR and RICS need to do more through curriculum development to promote cultural change and lessen the impact of professional background on mediation style.

A related issue concerns the need for accrediting and/or nominating bodies to take account of and certify competence in particular mediating styles, and for this to be documented in their databases and taken account of in referral practices. 
Thirdly, the concern expressed regarding correct application of mediation styles, particularly the evaluative style, suggests that there is scope for review or development of codes of practice to guide the correct implementation of various models of mediation. This must be underpinned by further research into best practice in respect of the various models of mediation in use by practitioners. Indeed such codes could be extended to define clearly also the role of advocates to address the concern of some practitioners that some advocates attempt to usurp their authority during mediation proceedings. In this regard, the recommendations of Mason (2012) for bringing about a change in culture are very apt. As an alternative to codes of practice, more attention needs to be paid to promoting reflective practice which as argued by Macfarlane (2002b) offers a more candid and complete approach towards achieving the right behaviours in mediation.

\section{References}

Agapiou, A. and Clark, B. (2011), "Scottish construction lawyers and mediation: an investigation into attitudes and experiences", International Journal of Law in the Built Environment, Vol. 3 No. 2, pp. 159-181

Agapiou, A. and Clark, B. (2012), "An empirical analysis of Scottish construction lawyers' interaction with mediation: a qualitative approach", Civil Justice Quarterly, Vol.31 No. 4, pp. 494-513

Agapiou, A and Clark, B. (2013), "A follow-up empirical analysis of Scottish construction clients interaction with mediation", Civil Justice Quarterly, Vol. 32 No.3, pp. 349-386

Alassini v Telecom Italia SpA (2010) [2010] 3 C.M.L.R. 17 
Alexander, N. (2006), Global trends in mediation, Kulver Law International, London

Alfini, J. (2008), "Mediation as a calling: addressing the disconnect between mediation ethics and the practices of lawyer mediators", South Texas Law Review, Vol. 49 No.4, pp. 829-839

Bar Council (2014) available at http://www.barcouncil.org.uk/search/?searchterm=mediation (accessed 16 January 2015)

Barrett, J., Levin, A. and Bridgewater, M. (2005), "Correspondents' reports: England and Wales: the engineer has left the building: the new ICE approach to dispute resolution", International Construction Law Review, Vol. 22 No.2, pp. 248-262

Bell, J. (2005), Doing your first research project: a guide for first-time researchers in education, health and social science. $4^{\text {th }}$ ed. Open University Press, Maidenhead.

Bowie, J. (2004), "Ethical issues in construction mediation: are there any rules?" Construction Lawyer, Vol. 24 No. 2, pp. 33-39

Brady, A. (2009), "Mediation developments in civil and commercial matters within the European Union", Arbitration, Vol. 73 No. 3. pp. 390399

Brooker, P. (2007), "An investigation of evaluative and facilitative approaches to construction mediation", Structural Survey, Vol. 25 No. 3/4, pp. $220-238$

Brooker, P. (2009), "Criteria for the appropriate use of mediation in construction disputes: Judicial statements in the English Technology and Construction Court", International Journal of Law in the Built Environment, Vol. 1 No.1, pp. 82-97 
Brooker, P. (2011), "Towards a code of professional conduct for construction mediators", International Journal of Law in the Built Environment, Vol.3 No.1, pp. 24-47

Brooker, P. and Wilkinson, S. (2010), Mediation in the construction industry: An international review, Spon Press, Abingdon.

Bryman, A. and Burgess, G (1994), Analyzing qualitative data, Routledge, London.

Burns, M. (2013), "Best person for the job? The benefits of appointing a commercial mediator", New Law Journal, Vol. 163 No. 7554

Bush, R. (2002), "Substituting mediation for arbitration: the growing market for evaluative mediation and what it means for the ADR field", Pepperdine Dispute Resolution Law Journal, Vol. 3. No. 1, pp. 111-131

Centre for Effective Dispute Resolution (2010), The Fourth Mediation Audit London: CEDR

Centre for Effective Dispute Resolution (2012), The Fifth Mediation Audit London: CEDR

Clark, B. (2009), "Mediation and Scottish lawyers: past, present and future", Edinburgh Law Review, Vol. 13, No. 2, pp. 252-77

Clark, B. (2012), Lawyers and Mediation, Springer, London.

Construction Task Force (1998) Rethinking Construction London: Department of Trade and Industry

Creswell, J. (2013), Qualitative inquiry and research design: choosing among the five approaches, Sage, London.

Denz, N. (2003), Collecting and interpreting qualitative materials. $2^{\text {nd }}$ ed. Sage, London. 
Dolder, C. (2004), "The contribution of mediation to workplace justice", Industrial Law Journal, Vol.33 No.4, pp.320-42

Dunnett v Railtrack plc (2002) [2002] EWCA Civ 303; [2002] 1 W.L.R. 2434; [2002] 2 All E.R. 850; [2002]

Gaitskell, R. (2005), "Current trends in dispute resolution", Arbitration, Vol. 71 No. 4 , pp. $288-299$

Genn, H. (1998), The Central London Court County Court Pilot Scheme: Evaluation Report, Department for Constitutional Affairs, London.

Genn, H. (2009), Judging civil justice (The Hamlyn Lectures) Cambridge University Press, Cambridge.

Golann, D. (2000), "Variations in mediation: how and why legal mediators change styles in the course of a case", Journal of Dispute Resolution, Vol.2000 No.1, pp. 41-61

Gould, N. (2009), The use of mediation in construction disputes: Summary report of the final results, A Research Project conducted by The Centre of Construction Law and Dispute Resolution, King's College London and the Technology and Construction Court

Gould, N., King, C. and Britton, P. (2010), Mediating construction disputes: An evaluation of existing practice, Kings College London, Centre of Construction Law and Dispute Resolution, London.

Hart, R. (1992), "Improving your chance of success during construction mediation." Arbitration Journal, Vol. 47 No. 4, pp. 14-20

Hensler, D. (2002), "Suppose it's not true: challenging mediation ideology", Journal of dispute resolution, Vol.2002 No. 1, pp. 81-89

Hibberd, P. and Newman, P. (1999), ADR and adjudication in construction disputes, Wiley- Blackwell, Oxford. 
Hudson-Tyreman, A. (2008) "Encouraged, pushed or forced - The order of the day? (Construction Industry Mediations)" Construction Law Journal, Vol. 24 No.2, p. 79

International Mediators Institute (2014) Code available at https://imimediation.org/imi-code-of-professional-conduct (accessed 16 January 2015)

Jackson, R. (2009) Review of Civil Litigation Costs: Preliminary Report Norwich: The Stationery Office

Jackson, R. (2010) Review of Civil Litigation Costs: Final Report Norwich: The Stationery Office

Lande, J. (1997), "How will lawyering and mediation practices transform each other?" Florida State University Law Review, Vol. 24 No.4, pp.839-43

Latham, M. (1994) Constructing the Team London: HMSO

Lowry, R. (2000), "To evaluate or not? That is the Question! (Mediation 2000 - Training mediators for the $21^{\text {st }}$ century)" Family and Conciliation Courts Review, Vol. 38, pp.48-58

Macfarlane, J. (2002a), "Culture change? A tale of two cities and mandatory mediation: Court-connected mediation", Journal of Dispute Resolution, Vol. 2002 No.2, p.241

Macfarlane, J. (2002b), Mediating Ethically: The Limits of Codes of Conduct and the Potential of a Reflective Practice Model, Osgoode Hall Law Journal, Vol. 40, No.1 pp.49-87.

Mason, J. (2012) How might the adversarial imperative be effectively tempered in mediation? Legal Ethics, Vol. 15 No.1., pp.111-122. ISSN $1460-728 X$

Mauthner, M., Birch, M., Jessop, J. and Miller, T. (2002), Ethics in qualitative research, Sage, London. 
McDermott, E. and Obar, R. (2004), "What's going on in mediation? An empirical analysis of the influence of mediator styles on party satisfaction and monetary benefit", Harvard Negotiation Law Review, Vol 9, pp. 75113

Menkel-Meadow, C. (1993)," Lawyer Negotiation: Theories and Realities What We learn from Mediation", The Modern Law Review, Vol. 56 No.3, pp. 361-379

Menkel-Meadow, C. (1995), "Whose dispute is it anyway? A philosophical and democratic defence of settlement (in some cases)" Georgetown Law Journal, Vol. 83 No.7, pp. 2663- 2696

Meyer, A. (1993) "Seegars Lecture - To adjudicate or mediate: That is the question", Valparaiso Law Review, Vol. 27. No. 2, pp 357-384

Meyer, J. and Leathes, M. (2008), "How mediators can obtain professional certification and thereby elevate their profession: a look at International Mediators Institute voluntary credentialing programme", Dispute Resolution Journal, Vol. 63. October, pp. 22-27

Moore, C. (2014), The mediation process: Practical strategies for resolving conflict, $4^{\text {th }}$ Ed. Jossey Bass, San Francisco.

Morse, J. (1994), Critical issues in qualitative research methods, Sage, London.

Mulcahy, L. (2001), "Can leopards change their spots? An evaluation of the role of lawyers in medical negligence mediation", International Journal of the Legal Profession, Vol.8 No.3, pp. 203-224

Nair, C. (2014) Mediation - A user's guide: Understanding and preparing for the mediation process. Hampshire mediation, Winchester.

Noce, D., Bush, R. and Folger, J. (2002), "Clarifying the theoretical underpinnings of mediation: implications for practice and policy", Pepperdine Dispute Resolution Law Journal, Vol. 3 No.1, pp.39-50 
Nolan-Hayley, J. (1998), "Lawyers, clients and mediation", Notre Dame Law Review, Vol. 73 No.5, pp. 1369-90

Nolan-Hayley, J. (2002), "Lawyers, non-lawyers and mediation: rethinking the professional monopoly from a problem-solving perspective", Harvard Negotiation Law Review, Vol. 7, pp.235-99

Patton, M. (1990), Qualitative evaluation and research methods, $2^{\text {nd }}$ ed. Sage, London.

Richards, L. (2009), Handling qualitative data: a practical guide, $2^{\text {nd }}$ ed. Sage, London.

Richbell, D. (2008), Mediation of construction disputes, Blackwell, London.

Richbell, D. (2012), Non-lawyers make the best mediators, Paper presented on 18/01/2012 at the Civil Mediation Council, available at http://mata.org.uk/wp-content/uploads/2010/06/The-non-rise-of-nonlawyer-Mediators.pdf (accessed 3 March 2014)

Riskin, L. (1996), "Understanding mediators' orientations, strategies, and techniques: a grid for the perplexed", Harvard Negotiation Law Review, Vol.1 No. 7, pp. 1-69

Riskin, L. (2003), "Decisionmaking in mediation: the new old grid and the new new grid system", Notre Dame Law Review, Vol 79 No. 1, pp. 1- 53

Roberts, S. (1992), "Mediation in the lawyer's embrace", Modern Law Review, Vol.55 No.2, pp.258- 264

Sapsford, R. and Jupp, V. (2006), Data collection and analysis. $2^{\text {nd }}$ ed. Sage, London.

Sharland, A. (2012). The guide to the principles of effective communication and conflict resolution. $2^{\text {nd }}$ Ed. Jossy Bass, New York. 
Stipanowich, T. (1996), "Beyond Arbitration: Innovation and evolution in the United States construction industry", Wake Forest Law Review, Vol. 31 No. 1 pp. $65-73$

Strasser, F. and Randolph, P. (2004), Mediation: A psychological insight into conflict resolution, Consortinum, San Francisco.

Strauss, A. \& Corbin, J. (1998), Basics of qualitative research: techniques and procedures for developing grounded theory, $2^{\text {nd }}$ ed. Sage, London.

Ter-Haar, R. and Ter-Haar, C. (2010), Remedies in construction law, Informa, London.

Thody, A. (2006), Writing and presenting research, Sage, London.

Thompson, P. (2004), "Enforcing rights generated in court-connected mediation - Tension between the aspirations of a private facilitative process and the reality of public adversarial justice", Ohio State Journal of Dispute Resolution, Vol.19 No.2

Tronson, B. (2006) "Mediation orders; Do the arguments against them make sense?" Civil justice quarterly, Vol. 25, pp. 412-417

Welsh, N. (2001), "Making deals in court-connected mediation. What's justice get to do with it?" Washington University Law Quarterly, Vol. 79 No. 3, pp. 787-789

Wissler, R. (2002), "Court-connected mediation in general civil cases: What we know from empirical research", Ohio State Journal on Dispute Resolution. Vol. 17. No. 3, pp. 641-703

Woolf, H. (1996) Access to Justice: final report to the Lord Chancellor on the civil justice system in England and Wales London: HMSO 